\title{
Selective Suppression of Insulin-induced Proliferation of Cultured Human Hepatoma Cells by Somatostatin
}

\author{
Chen-Kung Chou, ${ }^{\star \star 5}$ Low-Tone Ho, ${ }^{*}$ Ling-Pai Ting, ${ }^{\ddagger}$ Cheng-po Hu, ${ }^{\star *}$ Tsung-Sheng Su, ${ }^{\star *}$ \\ Wen-Chang Chang," Chen-Shian Suen," Ming-Ya Huang,* and Chungming Chang ${ }^{\star *}$ \\ *Department of Medical Research and Department of Internal Medicine Veterans General Hospital, Taipei; Taiwan, Republic of China; \\ ${ }^{\ddagger}$ Graduate Institute of Microbiology and Immunology, National Yang-Ming Medical College, Taipei, Taiwan, Republic of China; \\ ${ }^{\S}$ Institute of Biological Chemistry, Academia Sinica, Taipei, Taiwan, Republic of China
}

\begin{abstract}
The effects of somatostatin (SRIF), insulin, and triiodothyronine (T3) on the growth of human hepatoma cells were investigated on the well-differentiated human hepatoma cell line Hep3B. Results showed that both insulin and T3 can stimulate cell growth of serum starved Hep3B cells at physiological concentrations. SRIF alone showed little growth-promoting activity. When added concurrently with insulin, however, SRIF suppressed the insulininduced cell proliferation in a dose-dependent manner. On the other hand, SRIF had no inhibitory effect on T3-induced cell proliferation.

SRIF is labile in the medium, with a half-life of about $2 \mathrm{~h}$ during culture incubation. SRIF did not disturb the insulin binding to its surface receptors nor inhibit the insulin-dependent receptor kinase activity of Hep3B cells in vitro. These results suggest that postreceptor regulation may be involved. The selective suppression by SRIF of insulin-induced cell growth provides an unique approach to the study of insulin actions on proliferation of human hepatoma cells.
\end{abstract}

\section{Introduction}

Liver is a good model for the study of growth control of mammalian cells since it has a strong ability to regenerate and responds to many hormones. In vitro studies indicate that hormones and growth factors such as glucagon, insulin, epidermal growth factor, etc., can stimulate the DNA synthesis of rat hepatocytes (reviewed in ref. 1). However, normal adult rat liver cells do not divide frequently in vivo. The estimated spontaneous proliferation rate of adult rat hepatocytes lies only in the range of $0.05 \%$ to $0.005 \%$ (2). The proliferation of normal hepatocytes may be regulated by the interactions of the cell with both growth factors and growth inhibitors. The growth inhibitor of normal human hepatocytes has not yet been identified.

Somatostatin (SRIF), ${ }^{1}$ a cyclic 14-amino acid peptide, was originally discovered as a hypothalamic inhibitor of pituitary growth hormone secretion (3). Recently, SRIF was also found in the pancreatic islets and throughout the gastrointestinal tract.

Address reprint requests to Dr. Chou, Department of Medical Research, Veterans General Hospital, Taipei, Taiwan, ROC.

Received for publication 21 August 1986.

1. Abbreviations used in this paper: DME, Dulbecco's modified Eagle's medium; SRIF, somatostatin; T3, triiodothyronine.

J. Clin. Invest.

(c) The American Society for Clinical Investigation, Inc. 0021-9738/87/01/0175/04 \$1.00

Volume 79, January 1987, 175-178
SRIF has been postulated to regulate the nutrient homeostasis by affecting gastrointestinal function and nutrient absorption (4, 5). In the present study, a well-differentiated human hepatoma cell line-Hep3B (6) is used to investigate the effect of SRIF on insulin and T3-induced cell proliferation of human hepatoma cells.

\section{Methods}

Materials. Fetal calf serum (FCS) and Dulbecco's modified Eagle's medium (DME) were from Flow Laboratories (Aryshire, Scotland). The cell culture plates were from Costar (Cambridge, MA). Somatostatin was from Calbiochem Corp. (La Jolla, CA). Insulin was from Novo Co. (Copenhagen, Denmark). Iodine-125 and [gamma ${ }^{32} \mathrm{P}$ ]adenosine 5 '-triphosphate were from ICN Radiochemicals, Inc. (Irvine, CA). Wheat germ agglutinin agarose was from Vector Co. (Burlingame, CA). Other chemicals were from Sigma Chemical Co. (St. Louis, MO).

Cell culture. Human hepatoma Hep3B cells were kindly given to us by Dr. B. Knowles (Wistar Institute, PA), then cultured in DME with $10 \%$ FCS. All cells were incubated in $7 \% \mathrm{CO}_{2}$ moist $\mathrm{CO}_{2}$ incubator at $37^{\circ} \mathrm{C}$.

Serum starvation of human hepatoma cells. Cells from confluent stock plates were trypsinized and plated into 24 -well cell culture plates at a density of $1 \times 10^{5}$ cells per well in DME with $10 \%$ FCS and were allowed to attach overnight. Cells were then washed three times with Hanks' balanced salt solution with $\mathrm{Ca}^{2+}, \mathrm{Mg}^{2+}, \mathrm{pH} 7.0$ and the medium was changed to DME without serum every $2 \mathrm{~d}$ for a total of $6 \mathrm{~d}$. Cells stopped dividing at the end of serum starvation.

Radioimmunoassay of SRIF. SRIF in the culture medium was determined by radioimmunoassay essentially as described previously (7). In brief, ${ }^{125} \mathrm{I}$-Tyr-SRIF was used as the tracer, together with a highly specific rabbit anti-SRIF serum (final dilution 1:100,000). Samples were incubated with the antisera, ${ }^{125}$ I-Tyr-SRIF $(8,000 \mathrm{cpm})$ and the assay buffer ( $50 \mathrm{mM}$ ammonium acetate, $150 \mathrm{mM} \mathrm{NaCl} ; 50 \mathrm{mM}$ EDTA and $0.5 \%$ bovine serum albumin) at $4^{\circ} \mathrm{C}$ for $48 \mathrm{~h}$. Separation of the free and bound form of SRIF was done by using $0.3 \%$ dextran-coated charcoal. The limit of detection using these assay conditions was $50 \mathrm{pg} \mathrm{ml}^{-1}$. The recovery of SRIF in culture media at zero time was $\sim 98 \pm 5 \%$.

Insulin binding assay. The $\mathrm{I}^{125}$-labeled insulin was iodinated by the chloroamine-T method with a specific activity of $150 \mu \mathrm{Ci} / \mu \mathrm{g}$ (8). For insulin binding assays, cells were plated in 24-well cell culture plates and were serum starved as described above. Cells were then washed with binding buffer [DME containing $20 \mathrm{mM}$ 4-(2-hydroxyethyl)-1-piperazinethanesulfonic acid, $1 \%$ bovine serum albumin $\mathrm{pH}$ 7.9] three times. The ${ }^{125}$ I-labeled insulin $(0.1 \mathrm{ng}, 20,000 \mathrm{cpm})$ was added with various amount of unlabeled insulin (0 to $125 \mathrm{ng}$ ) with or without $\operatorname{SRIF}(0.5 \mu \mathrm{g})$ in a final volume of $0.25 \mathrm{ml}$. Cells were incubated at $25^{\circ} \mathrm{C}$ for $90 \mathrm{~min}$ when the insulin binding reached equilibrium, then washed with icecold binding buffer, solubilized with $0.1 \%$ sodium dodecyl sulfate (SDS) and counted on a $\gamma$-counter.

Phosphorylation of the insulin receptors of Hep $3 B$ cells in vitro. The insulin receptors of Hep3B cells were solubilized and partially purified through wheat germ agglutinin agarose, as described previously (9). Par- 
tially purified Hep3B insulin receptors (70 $\mu \mathrm{g}$ of protein) were incubated with $10^{-7} \mathrm{M}$ of insulin in the absence or presence of different concentrations of SRIF for $45 \mathrm{~min}$ at room temperature in $50 \mathrm{mM}$ Hepes buffer pH 7.6 containing $5 \mathrm{mM} \mathrm{Mn}{ }^{2+}$. The phosphorylation reaction was initiated by adding $\left.\mathrm{r}-\mathrm{l}^{32} \mathrm{P}\right] \mathrm{ATP}$ (final concentration $50 \mu \mathrm{M}, 10 \mu \mathrm{Ci} / \mathrm{nmol}$ ). The reaction was continued for $1 \mathrm{~min}$ at $37^{\circ} \mathrm{C}$ and stopped by adding SDS sample buffer to make a final concentration of $1 \%$ SDS, $0.2 \mathrm{M}$ mercaptoethanol, $10 \%$ glycerol. Samples were boiled at $100^{\circ} \mathrm{C}$ for $3 \mathrm{~min}$ and subjected to SDS-polyacrylamide gel electrophoresis.

Gel electrophoresis and autoradiography. Samples were run on $10 \%$ polyacrylamide slab gel in the presence of $0.1 \%$ SDS, using the procedure of Laemmli (10). After staining with Coomassie Brilliant Blue, and destaining, the gels were dried and subjected to autoradiography at $-70^{\circ} \mathrm{C}$ using Fuji x-ray film.

\section{Results}

After the cell growth was arrested by $6 \mathrm{~d}$ serum starvation, human hepatoma Hep3B cells were continuously cultured in DME alone or with various amounts of porcine insulin, T3 and SRIF added. As shown in Fig. 1, the insulin and T3 induced a dosedependent stimulation of cell proliferation of Hep3B cells. SRIF exerted only a little, but significant, growth-promoting activity. For both insulin and T3, the minimal effective concentration to stimulate the growth of serum-starved Hep3B cells was about $10^{-10} \mathrm{M}$. When SRIF was added simultaneously with insulin and T3, only the growth-promoting activity of insulin was inhibited (Fig. 2). The inhibitory effect of SRIF towards insulininduced cell growth was dose dependent. Similar observation was made on FCS; that is the proliferation of serum-starved

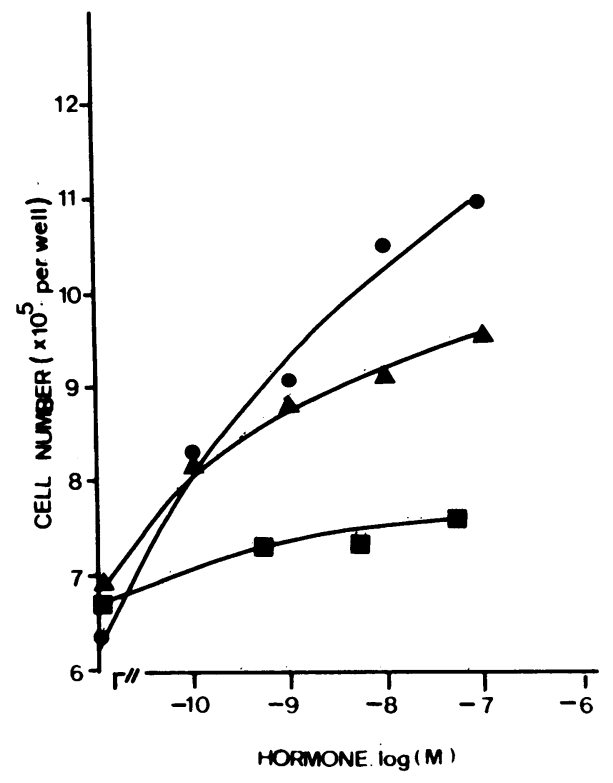

Figure 1. Effect of T3, insulin, and SRIF on cell growth of serumstarved human hepatoma cells Hep3B. Cells were plated into 24-well cell culture plates at a density of $1 \times 10^{5}$ cells per well and serum starved as described in Methods. After a 6-d serum starvation, the medium was changed to DME alone or various amounts of porcine insulin, T3, and SRIF were added. Cells were incubated with or without hormones for another $2 \mathrm{~d}$; and the cell number in each well was determined by hemocytometer. Each point represents the average of triplicate wells with standard deviation $<10 \%$. The experiment presented here was performed four times with similar results. (solid circle, insulin; solid triangle, T3; solid square, SRIF)

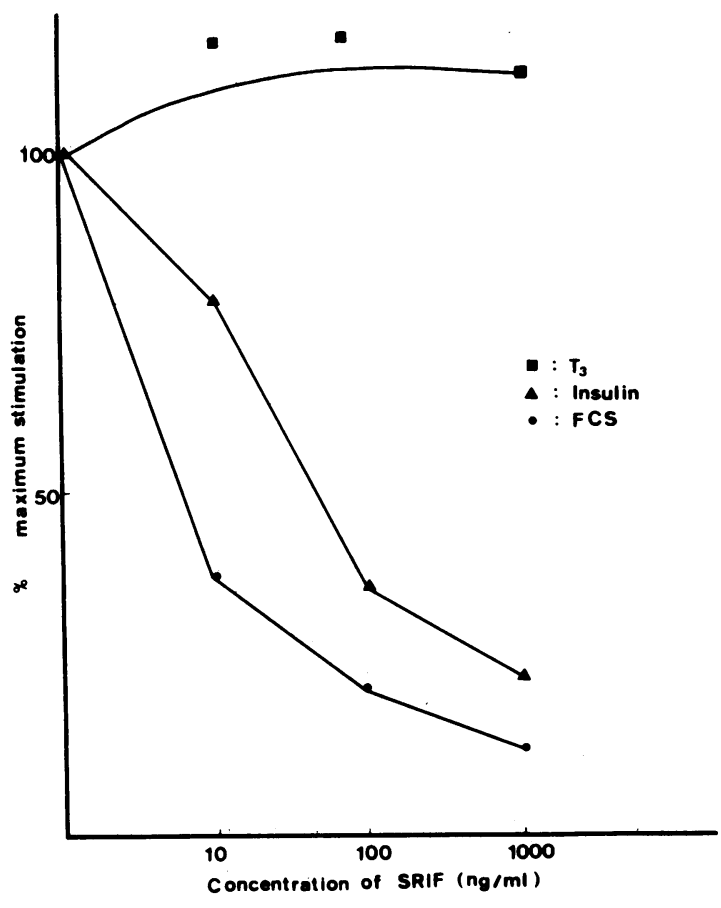

Figure 2. Inhibitory effect of SRIF on hormone stimulated cell growth of Hep3B. The cells were plated in 24-well cell culture plates and were serum starved as described in the legend of Fig. 1 . The cells were then incubated in the freshly changed DME for $48 \mathrm{~h}$ in the absence or presence of various concentrations of SRIF simultaneously with $0.1 \mu \mathrm{M}$ of porcine insulin (solid triangle), $10 \%$ FCS (solid circle) or $0.1 \mu \mathrm{M}$ of T3 (solid square), respectively. After a 2-d incubation, the cell number in each well was determined by hemocytometer. Percentage of maximal stimulation of Hep3B in the presence of SRIF was calculated by the following formula:

cell number in the well with hormone plus SRIF

$$
\text { - cell number in the control well }
$$

cell number in the well with hormone alone

$$
\text { - cell number in the control well }
$$

Each point represents the average of triplicate wells and the experiment has been repeated three times with similar findings.

Hep3B cells induced by $10 \%$ fetal calf serum was also inhibited by SRIF (Fig. 2). On the other hand, the growth-promoting activity of T3 was not inhibited by SRIF at all.

Since the inhibitory effect of SRIF was observed after $2 \mathrm{~d}$ incubation, the disappearance rate of SRIF under our culture condition was thus determined. Radioimmunoassay using a specific antiserum against SRIF was performed to determine the amount of SRIF remaining in the cultured media. Fig. 3 shows the degradation of SRIF during incubation with cultured cells. The disappearance rates of SRIF were very similar among specimens incubated with T3-treated Hep3B cells, insulin-treated Hep3B cells and Hep3B cells alone. The half-life of SRIF in the culture medium was estimated to be $2-3 \mathrm{~h}$.

The current model of insulin action implies that an interaction with the insulin receptor at the cell surface initiates all the subsequent effects of the hormone including growth promoting activity (11). Selective suppression of insulin inducedcell growth by SRIF may result from the interference of insulin binding with the cell surface receptors, or from impairment of the insulin receptor kinase activities directly by SRIF. To test 


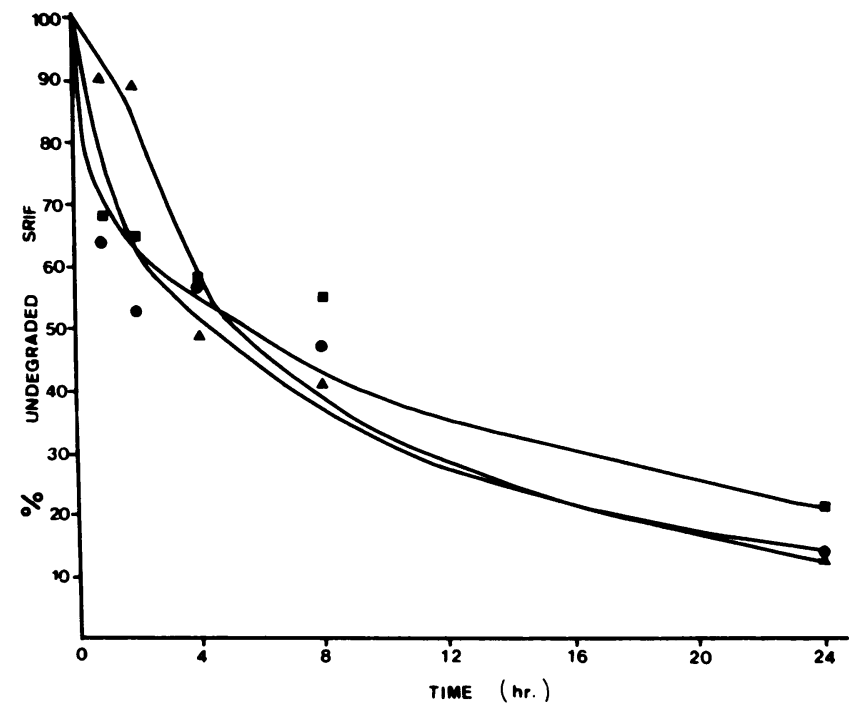

Figure 3. Time course of SRIF remaining in the culture medium of Hep3B cells. Hep3B cells were plated in a 24-well plate and serum starved as described in the legend of Fig. 1. After a 6-d serum starvation, medium was changed with DME plus SRIF $\left(1 \mu \mathrm{g} \mathrm{ml}^{-1}\right)$ (solid circle), and with $10^{-7} \mathrm{M}$ insulin (solid triangle), with $10^{-7} \mathrm{M} \mathrm{T} 3$ (solid square), then incubated at $37^{\circ} \mathrm{C}$. Medium was taken from each well at different time intervals. Aprotinin and EDTA were added to the medium immediately to final concentration of $500 \mathrm{IU} \mathrm{ml}^{-1}$ and $5 \mathrm{mM}$, respectively, and then stored at $-70^{\circ} \mathrm{C}$ before assay. Radioimmunoassay of SRIF in the culture medium was performed as described in Methods.

this hypothesis, insulin binding on Hep3B cells was determined in the presence of SRIF. Specific binding of labeled insulin on monolayered Hep3B cells was observed (Fig. 4). The apparent dissociation constant $\left(K_{d}\right)$ of the insulin receptors and the total receptor number on Hep3B cells were estimated by Scatchard analysis of the binding data as $5 \times 10^{-10} \mathrm{M}$ and 85,000 receptors per cell, respectively, in both the presence and absence of SRIF. Therefore, neither the affinity nor the total number of insulin receptors on Hep3B cells was affected by SRIF at concentrations as high as $2 \mu \mathrm{g} \mathrm{ml}^{-1}$.

The protein kinase activity of the partially purified insulin receptors was also examined. Insulin stimulates the autophosphorylation of the $\beta$-subunit of the insulin receptor of Hep3B in vitro with half-maximal concentration of $5 \mathrm{mM}$. SRIF, at a concentration of $2 \mu \mathrm{g} \mathrm{ml}^{-1}$, shows no significant effect on the insulin-dependent autophosphorylation of $\beta$-subunits of the insulin receptor (Fig. 4, inset).

\section{Discussion}

The growth promoting activity of insulin and T3 has been demonstrated in cultured rat hepatocytes $(12,13)$, but not reported for human liver cells $(12,13)$. The present study showed that insulin and T3 also stimulate serum starved human hepatoma cells Hep3B to proliferate in a chemically defined media. The dose response of insulin-stimulated cell growth in Hep3B cells occurs over a wide range of concentration (from $0.1 \mathrm{nM}$ to 1 $\mu \mathrm{M})$. At low concentration ( $1 \mathrm{nM})$, insulin is likely to act through the high affinity insulin receptor with $K_{d}$ of $0.5 \mathrm{nM}$. On the other hand, the mitogenic activity of insulin at high concentration

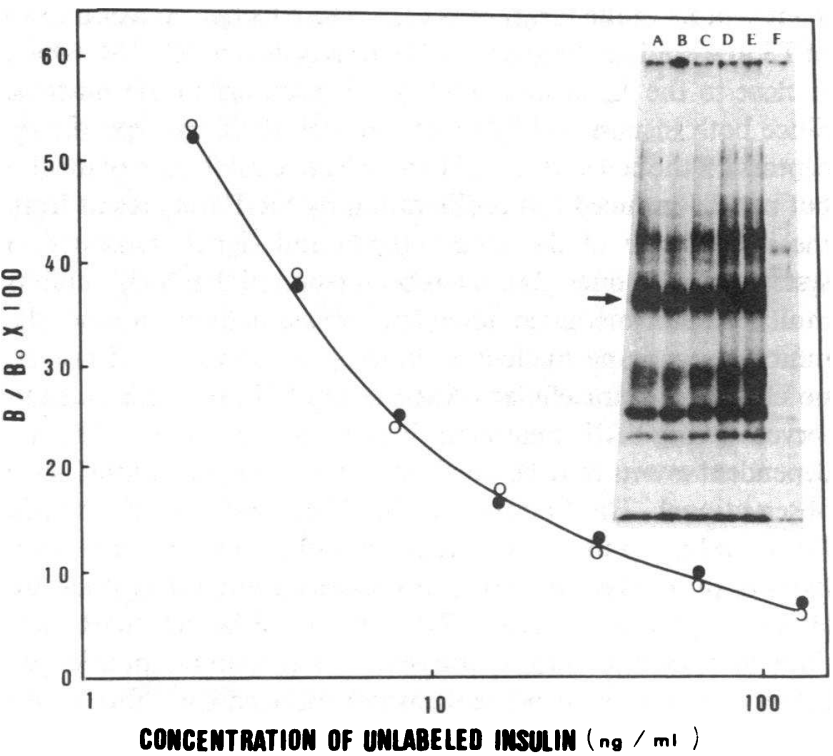

Figure 4. Displacement of ${ }^{125}$ I-labeled insulin binding to the insulin receptors of Hep3B by unlabeled insulin in the absence (solid circle) or in the presence of SRIF (open circle). Binding of ${ }^{125}$ I-labeled porcine insulin $\left(100 \mu \mathrm{Ci} \mu \mathrm{g}^{-1}\right)$ to Hep3B cells was performed as described in Methods. Bo is the total binding of ${ }^{125}$ I-labeled insulin to Hep3B cells in the absence of unlabeled insulin and represents $\sim 40 \%$ of total

${ }^{125}$ I-labeled insulin added in each well. (Inset) the effect of SRIF on the phosphorylation of the insulin receptor of Hep3B cells in vitro. Lanes $A-F: 70 \mu \mathrm{g}$ of partially purified insulin receptors were incubated alone (lane $F$ ), with $10^{-7} \mathrm{M}$ of insulin (lane $E$ ), and with $10^{-7} \mathrm{M}$ insulin plus $2 \mathrm{ng} / \mathrm{ml}$ SRIF (lane $D$ ), $20 \mathrm{ng} / \mathrm{ml}$ SRIF (lane $C$ ), $200 \mathrm{ng} / \mathrm{ml} \mathrm{SRIF}$ (lane $B$ ) and $2 \mu \mathrm{g} / \mathrm{ml}$ (lane $A$ ) SRIF, and assayed for insulin receptor phosphorylation as described in Methods. (Arrow) indicates the 94,000-mol wt phosphorylated $\beta$-subunit of insulin receptor.

may mediate through both the insulin and the insulinlike growth factor I receptor as suggested by several laboratories (14-16).

For the first time, we showed that SRIF selectively inhibits insulin-induced, but not T3-induced, cell growth of human hepatoma cells. Such a suppressive effect of SRIF was also observed in insulin stimulated $\left[{ }^{3} \mathrm{H}\right]$ thymidine incorporation in Hep3B cells (data not shown). Our finding indicates that the inhibitory effect of SRIF is not directly caused by the cytotoxic effects of SRIF against tumor cells, since SRIF alone slightly stimulated Hep3B cells to grow and it also does not inhibit T3-induced cell growth. The inhibition of growth-promoting activity of FCS further supports the hypothesis that this suppressive effect of SRIF may be significant in vivo.

The concentration of SRIF needed to inhibit the growthpromoting activity of insulin on Hep3B cells was about $10 \mathrm{ng}$ $\mathrm{ml}^{-1}$, which is $\sim 10$ to 100 times higher than the concentration of SRIF in the circulation $(17,18)$. Such a discrepancy may be attributed to the labile nature of SRIF during these particular experimental conditions. Recently, it was estimated that the halflife of infused SRIF in the plasma of normal human subjects is only $\sim 2 \min (7)$. However, SRIF has also been identified in pancreas (18) and gastric mucosa (19), and functions as paracrine. It is possible that SRIF appears in relatively high local concentration and functions regionally (i.e., paracrine) $(20,21)$ to regulate hepatocyte proliferation in vivo.

The biological activities of T3 have been shown to be mediated through the interaction of thyroid hormone with nuclear 
T3 receptors in the target cells (22). The effective concentration of T3 to stimulate the growth of Hep3B cells was $10^{-10} \mathrm{M}$, which is close to the $K_{d}$ of high affinity T3 receptors in the nucleus. Since both insulin and SRIF act through their own specific receptors on the cell surface (23), the selective inhibition of insulin but not T3-induced cell proliferation by SRIF may result from the interference of the membrane-bound signal transduction systems of hormones (24). It has been reported that SRIF inhibits multi receptor-mediated adenylate cyclase activity through the inhibitory guanine nucleotide binding protein (25). However, no change of intracellular cAMP level of Hep3B cells was observed during SRIF treatment, indicating that some cAMP-independent events may be involved in SRIF actions (unpublished observations). The finding that SRIF did not prevent insulin from binding to its surface receptors nor inhibit the kinase activity of purified insulin receptors raises an interesting question about the mechanism of SRIF actions. Whether SRIF acts through its own receptor to interfere with insulin receptor kinase activity in vivo or to prevent insulin induced $\mathrm{Ca}^{2+}$ flux is not clear at present but is currently under investigation.

\section{References}

1. Leffert, H. L., K. S. Koch, T. Moran, and B. Rubalcava. 1979. Hormonal control of rat liver regeneration. Gastroenterology. 76:14701482.

2. Leffert, H. L., K. S. Koch, P. J. Lad, H. Skelly, and B. deHemptinne. 1982. Hepatocyte Regeneration, Replication, and Differentiation. in The Liver: Biology and Pathobiology, (I. B. Arias, H. Popper, D. Schachter, and D. A. Shafritz, eds.) 601-614 (Raven Press, New York, 1982).

3. Brazeau, P., W. Vale, R. Burgus, N. Ling, M. Butcher, J. Rivier, and R. Guillemin. 1973. Hypothalamic polypeptide that inhibits the secretion of immunoreactive pituitary growth hormone. Science (Wash. DC). 179:77-79.

4. Zyznar, E. S., A. O. Pietri, V. Harris, and R. H. Unger. 1981. Evidence for the hormonal status of somatostatin in man. Diabetes. 30: 883.

5. Schusdziarra, V., V. Harris, A. Arimura, and R. H. Unger. 1979. Evidence for a role of splanchnic somatostatin in the homeostasis of ingested nutrients. Endocrinology. 104:1705.

6. Aden, D. P., A. Fogel, S. Plotkin, I. Damjanov, and B. B. Knowles. 1979. Controlled synthesis of $\mathrm{HBsAg}$ in a differentiated human liver carcinoma-derived cell line. Nature (Lond.). 282:615-616.

7. Ho, L. T., R. L. Chen, T. Y. Chow, J. C. Fong, P. S. Wang, and C. K. Chou. 1986. Pharmocokinetics and effects of subjects. A two compartment open model. Clin. Physiol. Biochem. A:257-267.

8. Cuatrecasas, P. 1971. Insulin-Receptor interactions in adipose tissue cells: direct measurement and properties. Proc. Natl. Acad. Sci. USA. 68:1264-1268.

9. Harrison, L. C., and A. Itin. 1980. Purification of the insulin re- ceptor from human placenta by chromatography on immobilized wheat germ lectin and receptor antibody. J. Biol. Chem. 255:12066-12072.

10. Laemmli, U. K. 1970. Cleavage of structural proteins during the assembly of the heat of bacteriophage T4. Nature (Lond.). 227:680-685.

11. Kahn, C. R. 1985. The molecular mechanism of insulin action. Annu. Rev. Med. 36:429-451.

12. Bucher, N. L. R., and M. N. Swaffield. 1975. Regulation of hepatic regeneration in rats by synergetic action of insulin and glucagon. Proc. Natl. Acad. Sci. USA. 72:1157-1160.

13. Short, J., R. F. Brown, A. Husakova, J. R. Gilbertson, R. Zemel, and I. Lieberman. 1972. Induction of deoxyribonucleic acid synthesis in the liver of the intact animal. J. Biol. Chem. 247:1757-1766.

14. King, G. L., C. R. Kahn, M. M. Rechler, and S. P. Nissley. 1980. Direct demonstration of separate receptors for growth and metabolic activities of insulin and multiplication-stimulating activity (an insulinlike growth factor) using antibodies to the insulin receptor. J. Clin. Invest. 66:130-140.

15. Van Wyk, J. J., D. C. Graves, S. J. Casella, and S. Jacobs. 1985. Evidence from monoclonal antibody studies that insulin stimulates deoxyribonucleic acid synthesis through the type I somatomedin receptor. J. Clin. Endocrinol. Metab. 61:639-643.

16. Flier, J. S., P. Usher, and A. C. Moses. 1986. Monoclonal antibody to the type I insulin-like growth factor (IGF-I) receptor blocks IGF-I receptor-mediated DNA synthesis: clarification of the mitogenic mechanism of IGF-I and insulin in human skin fibroblasts. Proc. Natl. Acad. Sci. USA. 83:664-668.

17. Webb, S., D. Kravetz, J. Bosch, J. A. H. Wass, J. Evans, R. Gomis, L. H. Rees, and J. Rodes. 1983. Splanchnic and hepatic metabolism of somatostatin: a study in cirrhotic patients with a portacaval shunt. Hepatology. 3:193-197.

18. Orci, L., and R. H. Unger. 1975. Functional subdivision of islets of Langerhans and possible role of D cells. Lancet. ii:1243-1244.

19. Schusdziarra, V., V. Harris, J. M. Conlon, and A. Arimura. 1978. Pancreatic and gastric somatostation release in response to intragastric and intraduodenal nutrients and $\mathrm{HCl}$ in the dog. J. Clin. Invest. 62:509518.

20. Jaspan, J., K. Polonsky, M. Lewis, and A. R. Moossa. 1979. Reduction in portal vein blood flow by somatostatin. Diabetes. 28:888892.

21. Kulkarni, P. G., F. M. Hoffman, and R. L. Shoemaker. 1979. Inhibition of $\mathrm{H}^{+}$secretion in frog gastric mucosa by somatostatin. Am. J. Physiol. 236:E784-787.

22. Oppenheimer, J. H. 1979. Thyroid hormone action at the cellular level. Science (Wash. DC). 203:971-979.

23. Aguilera, G., D. S. Parker, and K. J. Catt. 1982. Characterization of somatostatin receptors in the rat adrenal glomerulosa zone. Endocrinology. 111:1376-1384.

24. Heisler, S., T. D. Reisine, V. Y. H. Hook, and J. Axelrod. 1982. Somatostatin inhibits multireceptor stimulation of cyclic AMP formation and corticotropin secretion in mouse pituitary tumor cells. Proc. Natl. Acad. Sci. USA. 79:6502-6506.

25. Koch, B. D., L. J. Dorflinger, and A. Schonbrunn. 1985. Pertussis toxin blocks both cyclic AMP-mediated and cyclic AMP-independent actions of somatostatin. J. Biol. Chem. 260:13138-13145. 